\title{
Children's Artistic Selves: \\ A Look at Children's Personal Relationship with Art \\ Smita Garg
}

This research is a quest to discover the kind of personal relationship children have with art. It will be easier to understand what I mean by "personal relationship with art" in context of my own experience.

Looking back at my childhood I realize that I lived in two very different worlds of art, one being at school and the other, my own. The differences in those two worlds were significant. First of all there was a difference in purpose. Art projects in school were facilitated under the art teacher's watchful eye while what I did away from school was self-directed. One had a framework designed by the teacher to work within; the other offered infinite freedom to do what I wanted to. And though I enjoyed the work I did in school, I had a deep attachment with what I did apart from it. It was that attachment which inspired me to seek a career in the arts.

The realization that these two worlds existed so distinctly did not quite come to me until I began to teach art myself. As I taught scores of children for approximately thirty minutes once a week, I found myself struggling to understand what art meant to them--were the exciting projects that I designed and planned for them so meticulously, affecting them, changing them in anyway? I wondered:

- What do children think when working on art projects?

- Do they have personal likes and dislikes in materials and themes being used, and if so, do art teachers ever take those into consideration?

- Do children work on art projects outside of school, on their own? What kind of projects are those? How many art teachers know about them?

- What does art mean to children, what role does it play in their lives?

Graue and Walsh say,

The literature related to young children is filled with reports of studies in which children have been the objects of Inquiry. Given the amount of work focused on children, it is surprising how little we know about their lives. Little if any attention is paid to the contexts in which children live. Where are those young ones whose actions change so much from home to school to playground? Where is the understanding of or even interest in, children's lived experience?

(From Studying Children in Context)

Indeed I knew next to nothing about the children I came across day after day, much less about their art activities outside of my classroom. In undertaking this research, it is my sincere desire to locate answers to all questions raised above but specifically to the core question: 


\section{What is children's personal relationship with art like?}

\section{The beginning}

In the spring of 1998 , I embarked on this research with a pilot study. I found I was comfortable working with children in the age group of eight to ten. I also decided that to begin with, I would simply leave a child with art material of his or her choice and observe what he or she did with it. The kind of research methodology that seemed most applicable to such a venture was the qualitative research methodology. I found a suitable subject in my neighbor's daughter. Eight years old Nikhita always spoke her mind. Working with her, I knew she would tell me exactly what she was thinking. Nikhita grew especially excited at the prospect of attending "extra art classes" (apart from those she attended at school) for free! Knowing her family personally, helped. Her parents let her come to my house as often as she wanted and for any number of hours at a time. She turned out to be an ideal person for this study.

Having worked with her in the spring of 1998 , I began to look for more research subjects. To keep my data somewhat consistent I wanted to continue working with eight to ten year old children only. A friend brought me in touch with eight year old Justin and his mother. "Justin likes to draw", his mother informed me during our first meeting. "Would you teach him how to draw?" she asked. I explained to her that my research required me to stay in the background and observe what children did on their own. She agreed to let Justin come to my house once a week anyway. Justin however, came with a package --eight year old Joshua. Joshua had been Justin's best friend for as long as he knew. Former neighbors, they continued to attend the same school and were in the same class.

In the following pages I will present an outline of my case studies and some observations, which I feel are crucial in understanding these children's relationship with art.

\section{Nikhita: The first case study}

An outline:

- The first thing that I did was to take Nikhita to a store, where she picked out art material she wanted to work with. I also offered her materials she had never worked with before such as "wet-set clay", "model magic" etc.

- The sessions took place in my house--being my neighbor she was familiar with surroundings, and had easy access to my house (she could come and go as it pleased her).

- I video- and audio-taped the sessions (Nikhita was aware of the camera but very comfortable with it).

- The sessions would go from a couple hours to four, even five hours (I must admit that she was very dedicated).

- The sessions were always led by her--she decided what to do, which materials to use, and for how long to continue a session. 


\section{Some observations}

The projects Nikhita worked on were quite distinct. Initially she felt that she had to end each session with a product, as is customary in school art classes. This however changed with time. She understood that she could actually take as much time as she wanted. Eventually, I saw her become more relaxed, less concerned about finishing work in one session. At one point she commented how happy she was that this art class had no constraints of any kind. It turned out that she spent most of her time preparing an artistic birthday gift for her sister.

\section{Nikhita's style of working}

She paid attention to details, spent a lot of time thinking, planning, and executing the task at hand. Before working with her, I was not aware of how much thought a child was capable of putting into her artwork. Besides she could think independently, follow her own instincts and ideas, make her own decisions and even adapt her drawings to suit situations. Once she made a watercolor painting of a sunset. As she drew mountains, clouds, and a sun, she also decided to add birds to the sky. On painting the sky blue, she accidentally went over the birds with her brush and I happened to comment about it. Her reply was, "It's not my fault--the birds flew into the sky!"

She worked with several materials: three kinds of clay (ordinary, wet-set and model magic), paper, watercolors, crayons, markers, playdough, to name a few. She drew sunsets, flowers, and a self-portrait. With clay, she made animals, flower vases with flowers, and the exquisite birthday gift. Her favorite material turned out to be ordinary clay.

\section{Role of art}

It was important to her that her work looked different from that of her classmates at school. She made sure she told me how it was different: "I sign my name different from others" or "I make flowers different from others" or "my sun is a bit different". I realized that Nikhita believed there was a typical way of drawing certain popular objects--and she tried to deviate from those stylistic depictions on purpose to exhibit her individuality. This sounded like an important function of art in her life--with her art she could show others and herself how she was different.

Nikhita spent five out of eight art sessions working on a gift for her sister's sixteenth birthday. She made a clay cake, complete with clay icing and clay candles in her sister's (and her) favorite colors. The cake came with a matching clay birthday card, a wrapping paper that she designed from scratch and a bag in which to present the cake. Her dedication to this project was extremely commendable. So was her determination in keeping this gift a secret from her sister for almost two months (it was prepared two months in advance). Art was thus a medium for her to create something special for a person she cared for, and in the process communicate her love for that person. 


\section{Joshua and Justin}

The children I worked with next were Joshua and Justin. They had been best of friends for a long time. Justin's mother had told me that they were virtually inseparable. Knowing that they were such good friends, I assumed that they must share a lot in terms of their artistic interests. I could not have been more mistaken. As the year progressed, very different personalities and interests began to appear.

I asked both boys what materials they wanted to work with. They told me what to get for them. I did not know these boys' families well enough to take them out shopping as I had done in Nikhita's case. I offered them my own box of new materials too.

The sessions took place in my house. They spent anywhere from a couple to three hours at a time. I video--and audio-taped the sessions (They were aware of the camera and very comfortable with it--even enacted instant plays in front of it). The sessions were always led by them individually--each decided what he wanted to do that particular day and which materials he preferred to use.

\section{Some observations}

Both boys' interests were diverse. At times they copied off each other but mostly they stuck to their individual styles and preferences. Joshua produced work that had few details but great use of innate engineering skills. Justin produced work that was realistic and detailed, exhibiting a keen sense of observation.

\section{Joshua's style of working}

Joshua loved to draw TV wrestlers, and liked to build things which were grandiose or could move. He was easily distracted: a little lady bug on the wall would be a big deal for him. It was normal for him to roll on the carpet every few minutes or play hide-and-seek, disturb Justin or drop one activity for another. However, when he got down to work on an idea that meant something to him, he would spend days on it. While working on a big, complicated project, he would still get distracted, leave the project for a few minutes, do something else and then come back to it. However, he never left a project unfinished. I was quite amazed/by his ingenuity and engineering skills--he would come up with ways to create a moving object made out of simple materials such as model/magic, rubber bands and toothpicks.

Joshua used markers to draw his TV wrestlers. He worked primarily with paper, ordinary clay and model magic--he was happier working in three dimensions. His masterpiece was a three-tiered, three-dimensional house made entirely out of paper. He also made a clock with a moving pendulum, an army tank with a canon ball that could be shot, and a few dinosaurs and aliens. 


\section{Justin's style of working}

Justin's passion was drawing race cars and accessories--he invented several models on his own. While Joshua enjoyed working in 3-dimensions, Justin stuck mostly to drawing. His drawings ranged from" Hot wheels" and "Rage racers" to monkeys climbing up a tree. Justin worked on his projects with unparalleled concentration. He decided at one point that he wanted to make a book of his car designs. In the book, besides the cars, he added a flag that could be used to signal the start and end of a race, a giant speedometer that showed the impossible speeds his cars could attain, and trophies that one could get on winning a race. Justin also worked with clay, model magic and paper but not as extensively or at a scale that Joshua did. However, everything that Justin made was full of realistic details--the tiny clay camera had a very real aperture and a hollow cylindrical space on one side to put the batteries in. He built an army camp with barracks, tents, campfires, tunnels and soldiers. He brought his favorite toy characters from home and played with them in the environments he created. Joshua joined him in those play activities.

Justin's favorite materials to work with were clearly paper and pencil. He would make something with clay but would always revert to drawing. Joshua was just the opposite. When occasionally Justin did work with clay or model magic, he would create characters such as dinosaurs, aliens, army tanks, and futuristic vehicles for his creatures.

\section{Role of art}

Both boys loved playing with the objects they created. Battles with aliens, soldiers fighting in army camps, football games, and wrestling matches were expertly enacted on my coffee table. Environments for these activities were created using materials available. Amazingly there seemed to be no end to these boys' skills and imagination in creating familiar, and strange creatures or objects. Even better was their expertise in bringing them alive through their play activities. For these boys, art was clearly a way to bring to life, worlds that existed only in their fantasies. But some of the work was more than that--it was about what they wanted from life. Joshua's three storied paper castle with interesting gadgets, nooks and crannies, staircases, columned spaces, windows, and doors was a giant masterpiece of a house that he wanted to live in. Justin's racing cars with unbeatable power showed his love for cars and creativity in designing them. He confessed he wanted to grow up to be an engineer who designed cars.

\section{Some final observations}

Each child, who I worked with, came across as a distinct person with individual likes and dislikes. There were significant differences in the materials and themes they used. There were differences also in the way they applied materials and techniques to their art projects. More importantly, I saw what was important and meaningful to them reflected in their art. For Nikhita, it was a wonderful way to commemorate an important event such as a sister's birthday, and a way to exhibit her individuality. For Justin and Joshua it was a natural way of making their imagination come alive, of turning their fantasies into tangible reality. 


\section{What lies ahead...}

At present this research is still at its fledgling stage. However, working with these children has been an exciting, invigorating and a learning experience. Gareth B. Mathews says quite aptly, "Parents and teachers are often so impressed with the burdens they bear in having to nurture, instruct, reassure, and inspire their children that they fail to appreciate what children have to offer to adults." (From The Philosophy of Childhood)

Today, I am infinitely grateful to Nikhita, Justin and Joshua for giving me so much time and allowing me to learn about them--from them. During next few months, I look forward to working with several more children. I believe that what I might find about children's personal relationship with art will prove to be useful for all art teachers and educators in our understanding of children and their world.
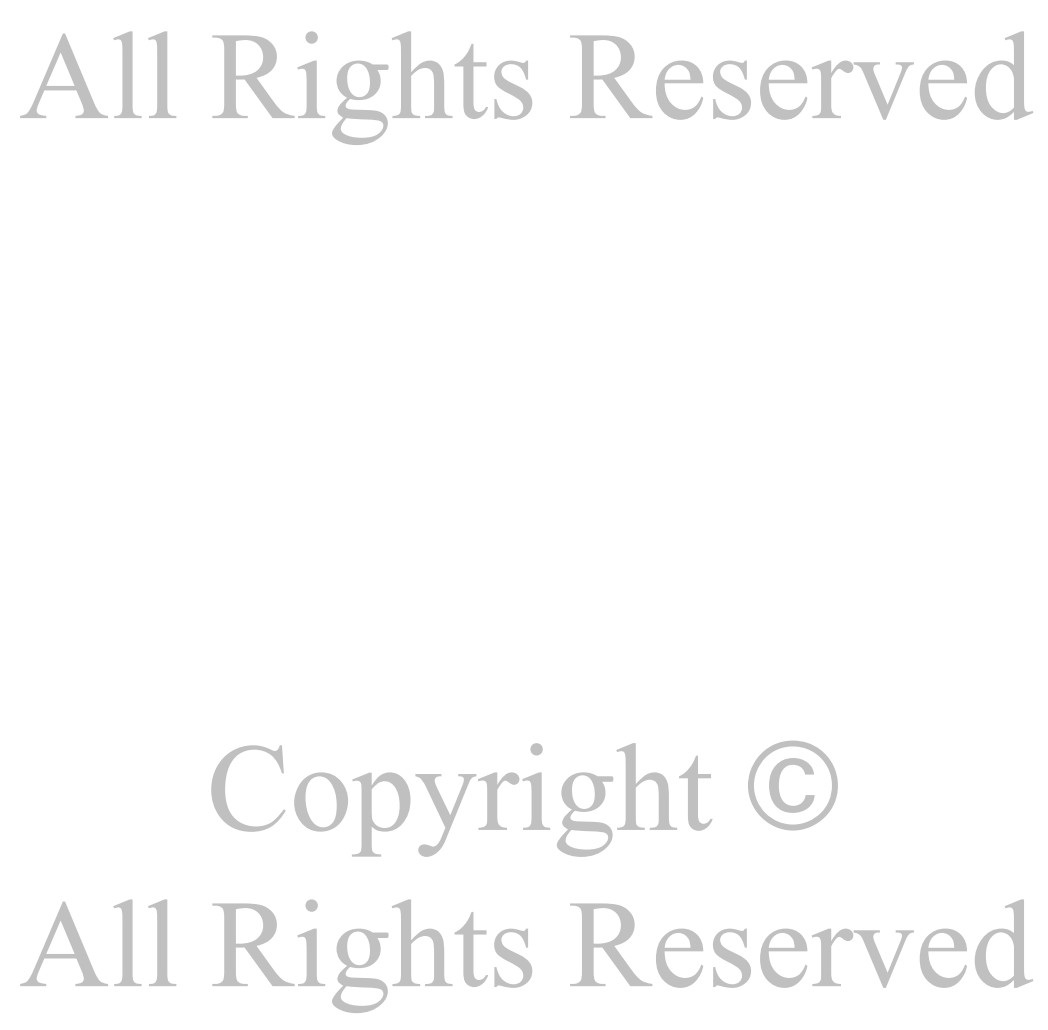